\title{
On Construction of Double - qualified English Teachers Teaching Team in Private Colleges
}

\author{
Lian Xue \\ Colloge of Foreign Languages and Literature, Wuhan Donghu University, Wuhan Hubei, 430212, \\ China
}

Key words: Private colleges, Double teacher, English teacher, Teaching team.

\begin{abstract}
The double teacher team is an important guarantee for the higher education and teaching work in colleges and universities to promote the overall teaching level. Therefore, in order to improve the effectiveness of English teaching in the process of organizing English teaching activities, We should actively strengthen the construction of the double teacher English teaching team, and provide good support for the comprehensive optimization of English teaching activities. This paper analyzes the existing problems in the construction of the teaching system of the double-qualified English teachers from the competency standards of the double-qualified teachers in the private colleges and universities, and puts forward the corresponding suggestions to solve the problems of the English teaching activities in private colleges Fully optimized.
\end{abstract}

\section{Introduction}

With the deepening of the educational reform in recent years, the training of high-quality teachers has been highly concerned by the educational institutions at all levels. In the course of organizing the teaching work, only teachers have high professional quality and can bear the Level of teaching tasks, the overall quality of education in China can be significantly improved. Based on this private colleges in the organization of teaching activities in the process is also committed to actively build English dual teachers, hoping to provide comprehensive support for the overall optimization of English teaching activities, effectively enhance the relevance of English teaching and scientific, For the students to develop high-quality compound talents to provide the appropriate protection.

\section{Competency Standards for Double Teachers in Private Colleges}

Double teacher refers specifically to the teachers who have both theoretical teaching ability and practical guidance ability. The knowledge system has the characteristics of job knowledge and dual knowledge of teaching and teaching, and can be oriented to all students, implement relatively scientific education and guidance to students, And students to build a good relationship between teachers and students, but also for enterprises and society, the school has a dual professional quality of high-quality talent. The basic ability of the dual-faculty teachers in private colleges includes the following aspects: First, the ability-based concept, that is, the professional education ability as the basis, emphasizes the prominent learners in the learning process of the dominant position in the teaching process will be accumulated Knowledge and access to relevant professional competence as a basic principle, and in the double teacher training should also be the ability to assess the core. Second, the concept of lifelong education, private research-oriented colleges and universities for the training of senior personnel training, so the teacher education and teaching practice should pay attention to the students to teach constantly updated professional knowledge, so private institutions of dual teachers should also have Lifelong education concept, to ensure that teachers can effectively promote the comprehensive ability to be improved, and effectively meet the students' learning needs. Third, the concept of diversified school. With the deepening of the reform of education and teaching, under the influence of the thought of cultural openness, the private colleges and universities in the world have gradually adjusted the teaching mode of education, breaking through the inherent boundaries between 
the traditional schools and the society, and organizing the open teaching activities. To further enhance the school to serve the community and serve the community functions, and promote the organic combination of production and research work. Affected by this, private colleges and universities double teachers should have a wide range of school capacity, to meet the open-ended private institutions of diverse education needs. Fourth, the concept of humanistic quality education. In the current period of knowledge economy transformation and development, the goal of personnel training in private colleges has changed, not only hope to realize the cultivation of students 'professional knowledge and skill, but also to cultivate students' professional moral quality, occupational health and psychological quality , And guide students to develop a sense of lifelong development. Therefore, the double teachers of private colleges and universities should maintain the importance of humanistic quality education, and integrate humanistic quality education in teaching practice, so as to provide important guarantee for the healthy growth of students.

\section{Problems in the Teaching Team Construction of Double - qualified English Teachers in Private Colleges}

Under the influence of economic globalization, the application of English language in the international community is more extensive, and the high quality English compound talents are extremely lacking, and it is imperative to cultivate students' English professional ability. This has a certain extent on the private institutions of personnel training work had a corresponding impact, private institutions in the organization to carry out personnel training in the process of further strengthening the emphasis on English teaching, and actively create a double teacher English teaching team, Hoping to provide good support for the cultivation of students' English professional quality [1]. However, it is found that there are still some problems in the construction of double teacher English teaching team, which will have corresponding adverse effects on the cultivation of English compound talents. Specifically, the private colleges and universities double teacher English teaching team construction work in the main problems in the following areas:

First of all, double teacher talent is highly lacking. At present, the composition of English teachers in private colleges and universities in our country is basically as follows: the teachers who have just been engaged in the work of teachers are strong, but the practical ability is poor. The working English teachers of public institutions do not sit in class, but they can provide the corresponding students Education guidance; provincial colleges and universities to promote personnel, practical education ability, but the theoretical level is low, poor knowledge update ability; foreign English teachers, English communication ability, poor educational ability. It can be seen that the lack of double teachers in English teachers of private colleges and universities has a certain negative impact on the scientific nature of education and the cultivation of students' comprehensive English quality.

Secondly, there is a lack of rationality in the evaluation system of English teacher title in private colleges. At present, the evaluation of English teachers in some private colleges and universities in our country mainly takes the level of academic research of teachers as a reference, which causes some English teachers to place the work center in academic research in order to obtain higher grade titles, neglect the education and teaching work, Which seriously limits the improvement of teaching level and the cultivation of students' comprehensive English quality, and is not conducive to the construction of the teaching team of double teacher English teachers in private colleges.

Finally, lack of effective teacher incentives. At present, China's private colleges have not yet developed a policy document on the construction of double-faculty teachers. In the absence of effective incentives, teachers are becoming less active in the case of double-qualified teachers, which generates a certain adverse effects for the construction. It can be seen that there are still big problems in the construction of double-qualified English teachers in private colleges at present, which seriously limits the improvement of teaching quality and the cultivation of students' comprehensive English quality. Therefore, the new period should also pay attention to strengthening the teaching of doubleTeam construction work attention, and actively create a double teacher English teaching team for the English teaching activities to create a comprehensive optimization of the conditions [2]. 


\section{Measures on Construction of Double - teacher English Teachers' Teaching Team in Private Colleges}

In order to solve the problems existing in the construction of the teaching system of the double-qualified English teachers in the private colleges and universities in our country, the private colleges and universities in the new period can formulate corresponding countermeasures for the specific problems in the process of actively strengthening the teachers' team construction, so as to effectively improve the construction of teachers The status quo, for the private colleges and universities to provide appropriate training for the training of English teachers, and effectively promote China's private colleges and universities in English teaching work in the new period to obtain new development.

\section{Reform and innovation of the educational model, and enhance the professional level of English teachers}

In the process of exploring the teaching team of the double-qualified English teachers in the private colleges, the school should realize the influence of the practice teaching activities on the students, and then adjust the educational curriculum structure and the teaching mode in combination with the training needs of the double-qualified English teachers, In the implementation of specialized education in the process of teaching teachers to cultivate the professional education ability, so that teachers develop good professional skills. At the same time, private colleges and universities should organize English teachers to participate in the training and training of double teacher teachers on a regular basis, and cultivate the double teacher education ability of English teachers, and gradually improve the overall quality of teachers and provide important guarantee for the professional development of teachers. In this way, through the education and training, the degree of specialization of English teachers in private colleges can be further improved, which can lay the foundation for the construction of the double teacher English teaching team, so that the construction of double-qualified English teachers in private colleges Better development results.

\section{The school provides policy support for the construction of the double teacher English teacher teaching team in practice}

English teachers in private colleges and universities are generally in the first line of education and teaching activities, after the completion of heavy teaching tasks often can not engage in academic research work, if the teachers will be all devoted to English teaching activities, their own professional education and practical skills Guidance ability to be cultivated, to explore the transition to double teacher, teachers of academic research time is bound to be greatly reduced, the teacher's title assessment have a negative impact. Based on this, in order to keep teachers in exploring the duality of English teachers in the development of the enthusiasm of private colleges should be based on teachers and established policy support. For the teachers to participate in scientific research work or to practice in the institutions to create good conditions, and then the English teachers of the double vocational quality to be cultivated to promote the dual-level English teacher teaching team building in the new period to achieve new development. In this way, under the support of the private colleges, the English teachers can cultivate the teachers and students through the training of the enterprises and institutions, and the teachers 'professional English ability and comprehensive education ability can be well cultivated, which has a positive effect on the construction of the double-qualified English teachers' teaching team.

\section{Actively learn from the domestic and international dual - English teachers teaching team building valuable experience}

Abroad, the training time of the double teacher English teachers is relatively early, and a lot of successful experiences are summed up in the long course of development. The construction of the double teachers is also achieved remarkable results. Therefore, private colleges and universities in the active construction of double-qualified teachers in the process, we can learn from foreign advanced 
experience for our dual-type English teachers teaching team to provide good support [4]. On the basis of a comprehensive analysis of the situation of the construction of double-qualified English teachers in private colleges and universities in our country, it is necessary to optimize the construction of double-qualified English talents in combination with students' English learning needs and the training of English talents in private colleges. Provide good support for private education in English. As a result of the experience of Danish double teacher training, private colleges and universities can carry out the combination of internal training and external training in the process of implementing double teacher education and training for serving English teachers, and cultivate the professional ability of English teachers. English teachers improve the overall quality of the corresponding support. Another example is the German dualism teaching model, so that English teachers at the same time to accept the school English professional continuing education and business English practice education, teachers to promote the English knowledge structure presents a duality characteristics, and then double the English as a core training, Effectively improve the quality of English teachers teaching for the quality of English students to provide good support.4. Government policy support, to adjust the structure of private English teachers in private institutions

In order to further enhance the level of the construction of the teaching system of the double-qualified English teachers in the private colleges, the government-related education departments are actively analyzing the dual-level English in the private colleges and universities. The government-related education departments have also made great efforts to promote the development of the dual- Teachers in the actual construction needs of the case, you can introduce the relevant policies to introduce vacancies, the dual teacher English teacher structure to make reasonable adjustments to further enhance the effectiveness of private teachers in the construction of dual English teachers. The related research shows that there are big differences between the secondary structure, the structure of academic structure and the structure of title structure in some private colleges and universities in our country at present. There are big differences between them and the public institutions. Salary level, the level of teachers 'welfare and the future development of teachers' personal development are different from those of public institutions. The attractiveness of teachers is low, and even excellent teachers are reluctant to engage in education and teaching in private colleges. The overall quality of education The improvement of the teaching team and the optimization of the construction of a certain adverse impact, double-grade English teachers construction effect is relatively poor. Therefore, the regional government departments should introduce the corresponding support policies, the salary level of teachers in private colleges to make appropriate adjustments, and then with the help of policy support for private institutions of English teachers to rationalize the structure of a reasonable [5]. At the same time, the human resources department should also aim at the corresponding teacher's career planning policy for the construction of the dual-teacher English teaching team in the private colleges and universities, and adjust the age structure, academic structure and title structure of the double-qualified English teachers. Provide appropriate protection for proofreading technology application talents. Only in this way, in the support of the government departments, the human resources sector and the private sector's own efforts, the dual-type English teacher teaching team building in the new period to achieve new development results for the private institutions of compound talents To promote the work of the comprehensive promotion to provide good support.

\section{Conclusions}

In view of the above, in the current English education is increasingly subject to the widespread concern of the community, private institutions in order to ensure the quality of English teachers to promote the future development of students, we should actively explore the corresponding double teacher English teaching team construction measures, Combined with the construction standards of the dual-level English teachers to develop appropriate strategies for the development of dual-level English teachers to provide comprehensive support to promote China's private colleges and universities in English teaching and personnel training work in the new era of new development. 


\section{References}

[1] Tang Linfei. On the Ways of Cultivating the Double Teachers' Team of Public English Teachers in Private Higher Vocational Colleges - Taking Zhejiang Yuying Vocational and Technical College as an Example, Liaoning Vocational and Technical College of Economics, Journal of Liaoning Economic Management Cadre College,2013(2):66-68.

[2] Cheng Can. On the Ways of Cultivating "Double - qualified Teachers" in Private Colleges, Journal of Chongqing Electronic Engineering Vocational College,2016,25(1):96-98.

[3] Zhai Lian. How to Improve the Quantity and Quality of "Double - qualified" English Teachers in Higher Vocational Colleges, Journal of Sichuan Vocational and Technical College,2013,23(2):125-127.

[4] Yang Lei. On the Cultivation of "Double Teacher" English Teachers in Applied Undergraduate Colleges, Charm of China,2014(14):196-196.

[5] Wu Yin. Reflections on the Construction of Double - qualified English Teachers in Higher Vocational Colleges, Knowledge guide,2016(23):117. 